\title{
The Relation between the Residual Stress and the Crazing in Polymer Films on Magnet Wires
}

\author{
by \\ Shigeo Masuda, Nobuyuki Asano \\ ( $R$ and D Group, Sumitomo Electric Ind. Co., Ltd., Osaka) \\ Toshihiko Tanaka, and Teruo Itoga \\ (Magnet Wire Division, Sumitomo Electric Ind. Co., Ltd., Nagoya)
}

\begin{abstract}
It is well known that crazing occurs when a magnet wire is immersed in an impregnating bath of varnish after the wire was coiled up. A quantitative study was carried out in this paper for clarifying the relation between the crazing and the residual stress in the polymer film on the wire. As test specimen were used magnet wires which had poor adhesion strength between the polymer film and the conductor. The crazing in the polymer film on the magnet wire occurred most severely between 3\% and 5\% elongation. The residual stress in the film attained a maximum value in the same range of elongation. That is, the crazing occurred most severely in the range of elongation where the stress in the polymer film was most hardly relaxed. A morphological study of crazing was made by using two types of magnet wires coated with cross-linked and linear polymers. The crazing observed in the cross-linked polymer films, polyesterimide, was identified as a sort of micro-cracks. In the case of linear polymer films, ployamide (Nylon 66), orientation of polymer chains in crazing was observed.
\end{abstract}

\section{巻線における皮膜内残留応力とクレージングの関係}

\author{
增田 重雄*・浅野 信之*。田中 敏彦**。系賀 輝雄**
}

（原稿受理：1975年 2 月 3 日）

\section{1，緒言}

巻線の主品種であるエナメル線は, 熱硬化性樹脂塗料を導体上 に薄く塗布焼付することを複数回繰返して製造される。乙のよう にして製造された巻線がコイル状に巻かれ，その後の含浸ワニス 処理工程で場合によってはクレージングを発生することはよく知 られている。一方，実験的には $3 \sim 5 \% の$ 伸長率の場合にクレ一 ジングが最も発生しやすいてともよく知られた事実である ${ }^{122)}$. 巻線におけるクレージングの発生はとりわけ皮膜の絶縁性を低下 させ電気機器の信頼性をそこなわせるために実用上非常に重要な 問題であり，その予防にいろいろな手段がとられてきた。巻線の クレージングに関する研究報告には，ポリビニールフォルマール において球晶発生に原因があるという説 ${ }^{11)}$ や粘弾性と熱力学を 組合せた定性的解橎 ${ }^{2)}$ ，さらに最近では伸長した後塗膜がある種 の溶剤に触れると, 分子鎖が配向し, この配向がクレーシシングの

* 住友電気工業秼研究開発本部 大阪市此花区恩貴島南之町 60 **住友電気工業侏機器電線事業部 名古屋市南区新郊通 $1-10$
原因であるという説年4) がある、しかしてれらの研究では，いず れも定量的な実験がなされていない。

巻線のクレージングは皮膜に応力が働いている状態で溶剤や溶 剂蒸気に触れた時に発生する。皮膜内の応力がクレージング発生 の要因であることは明らかである，そのために，皮膜内の応力 ${ }^{576)}$ を定量的に把握するととがクレージングを定量的に理解するうえ で最も必要と考えられる。ところか電気機器に用いられる巻線は 皮膜と導体間の接着が良好な複合材料であり，皮膜のみに働いて いる応力を測定するてとは困難である. そのために, 巻線のクレー ジングは学問的にも興味深い問題を投げかけていただけでなく， 実用面からも重要な問題であるにもかかわらず充分な研究がなさ れなかったものと思われる。

巻線のクレージングで特徽的と思われるととは次のてとであ る. (1)伸長率 $3 \sim 5 \%$ でクレージングの発生が最大となるとと,

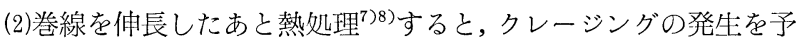
防できるてと.(3)ある種の巻線はクレージングが発生しても適当 な熱処理によって消失させることができるてと．著者らは巻線の 
製造に際し導体を酸化させ，導体と皮膜間の接着の弱い巻線を製 造し，乙れを試験試料として用い，伸長後の皮膜内の残留応力を 定量的に測定する方法を開発した。この方法を用いることによっ て伸長後の皮膜内残留応力を測定し，巻線のクレージングとその 伸長率との関係を定量的に把握できたので報告する．また，巻線 のクレージングがクラックであるのか，あるいは配向であるのか を架橋型高分子のポリエステルイミド及び直鎖状高分子のポリア ミド，ナイロン66）にそれぞれ発生させたクレージングを電子顕 微鏡を用いた観察から形態学的に考察したので併せて報告する。

\section{2. 実}

験

$2 \cdot 1$ 試 料

本実験に用いた巻線の試料は Table I に示すポリエステルイ ミド，ポリミドイミド，及びポリアミドである。これらの試料 から得られる絶縁皮膜の粘弾性挙動を Fig. 1 亿示す.

\section{$2 \cdot 2$ 皮膜内残留応力の測定}

一定長さの試料を定速で伸長すると時間と共に加えられる応力 は増加する (Fig. 2, OA)，次に， $t_{1}$ で伸長を停止すると応力は 時間と共に緩和する (Fig. $2, \mathrm{AB}) . t_{2}$ で皮膜の円周をナイフで

Table I. Samples (Bare wire, $1 \mathrm{~mm}$ Dia.).

\begin{tabular}{l|lccc}
\hline & Enamel & $\begin{array}{l}\text { Film } \\
\text { thickness } \\
(\mathrm{mm})\end{array}$ & $\begin{array}{l}\text { Glass } \\
\text { transition } \\
\text { temp. }\left({ }^{\circ} \mathrm{C}\right)\end{array}$ & $\begin{array}{l}\text { Melting } \\
\text { point } \\
\left({ }^{\circ} \mathrm{C}\right)\end{array}$ \\
\hline PEI & Polyesterimide*1 & 0.051 & 188 & - \\
PAI & Polyamideimide*2 $^{* 2}$ & 0.050 & 282 & - \\
Nylon 66 & Polyamide*3 $^{*}$ & 0.051 & 60 & 259 \\
\hline
\end{tabular}

*1 “Isomid" (Nisshoku-Schenectady Chemical Co.)

*2 Polyamideimide (Sumitomo Electric Co.)

*3 "CM-3001" (Toray Co.)

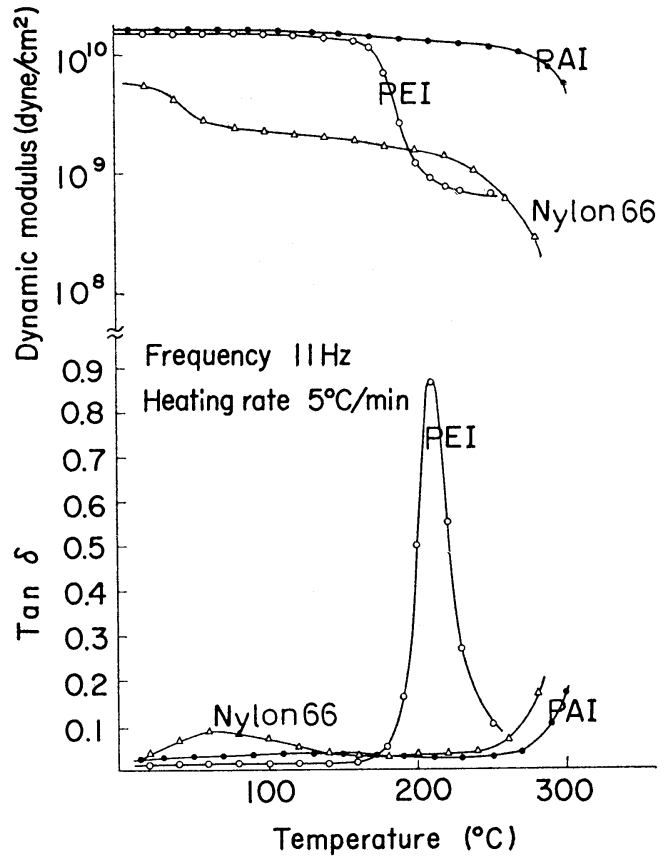

Fig. 1. Viscoelastic behavior or Polyesterimide (PEI), Polyamideimide (PAI) and Polyamide (Nylon 66$.

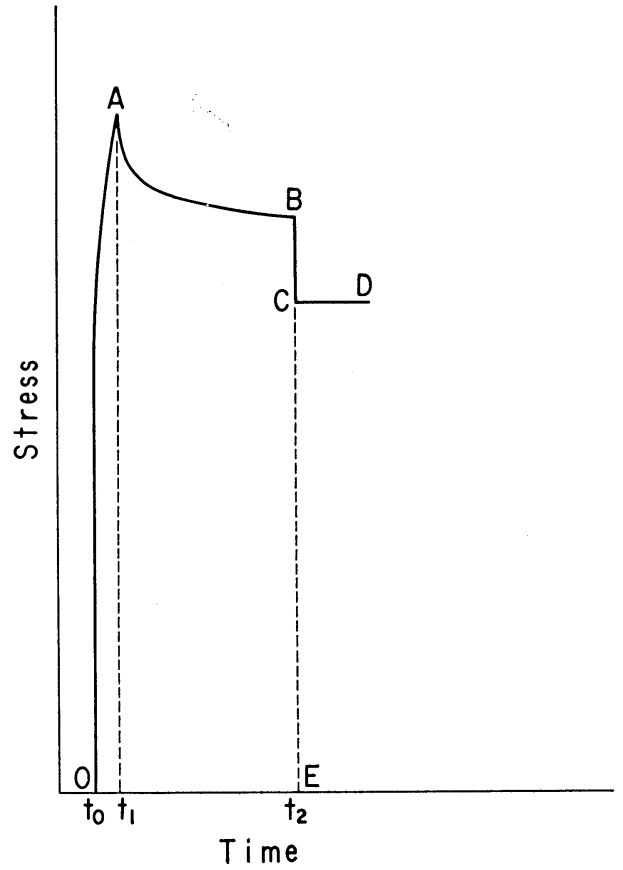

Fig. 2. Residual stress of film after elongation.

切ると皮膜は収縮する．同時に皮膜が分担していた応力分だけ応 力が急激に低下する (Fig. 2, BC)。乙の低下した応力 BCが皮膜 内の残留応力であり， $\mathrm{CE}$ は導体の残留応力である. 試料の伸長 率は $t_{1}$ を変えるととによって変化させることができる，なお Fig. 2 から理解できるように $\left(t_{2}-t_{1}\right)$ はいずれの場合も一定にす る必要がある。

\section{$2 \cdot 3$ クレージング発生による応力緩和の測定}

$t_{2}$ で皮膜を切断する代りに溶剂を皮膜に塗布すると，皮膜にク レージングが発生し皮膜の応力は B から Cへと低下する (Fig. 3).

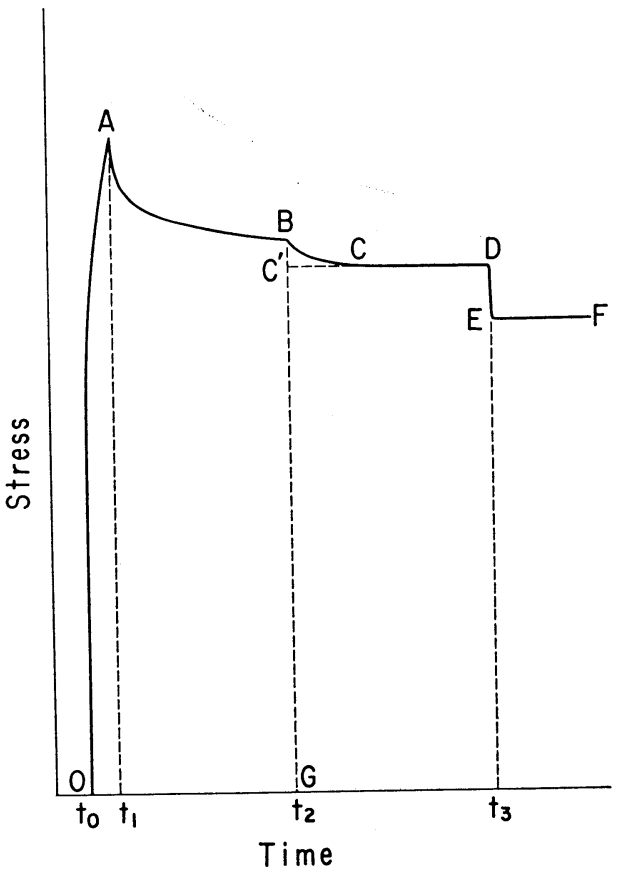

Fig. 3. Stress relaxation by crazing and residual stress of film after crazing. 
$\mathrm{C}$ から BG 一垂線を下しその点を $\mathrm{C}^{\prime}$ とする， $\mathrm{BC}^{\prime}$ がクレージン グ発生による応力緩和量である. クレージング発生後, $t_{3}$ で皮膜 の円周をナイフで切断すると皮膜は残留応力に従って収縮する為 に残留応力が求まる (Fig. 3, DE). DE はクレージング発生後の 皮膜内残留応力である.

\section{$2 \cdot 4$ 測定装置及びその他の条件}

本実験には島津製作所製の「オートグラフ S-100」を用いた。 皮膜の切断及びクレージング発生の為の溶剤塗布は伸長後 1 分経 過後に行なった。試料のチャック間距離は $200 \mathrm{~mm}$, 伸長速度は $1 \mathrm{~mm} / \mathrm{sec}$, クレージングはメチルエチルケトン (MEK) をガー ゼに含ませて塗布することにより発生させた。

\section{3. 結}

果

試料ポリエステルイミド，ポリアミドイミド及びポリアミド

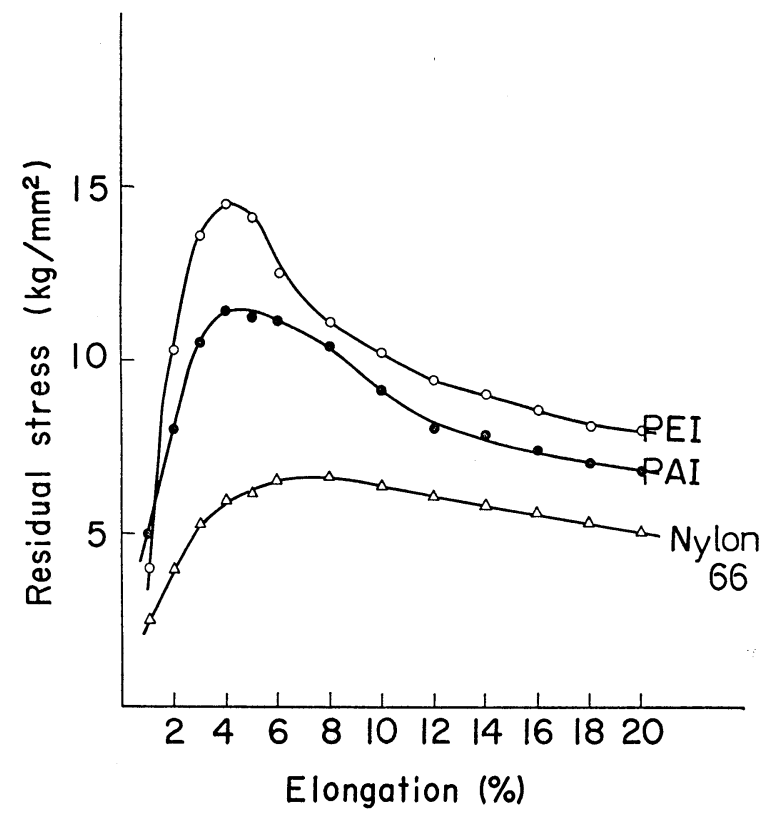

Fig. 4. Residual stress vs. elongation curves of Polyesteairnide (PEI), Polyamideimide (PAI), and Polyamide (Nylon 66).

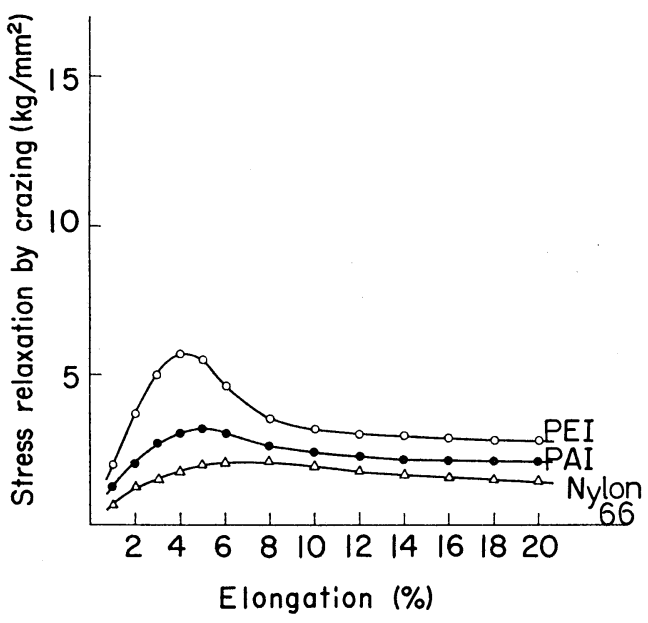

Fig. 5. Stress relaxation by crazing vs. elongation curves of Polyesterimide (PEI), Polyamide (PAI), and Polyamide (Nylon 66).
の伸長率を $1 \%$ から $20 \%$ まで変化させた時の皮膜内残留応力を Fig. 4 に，またクレージング発生による応力の緩和量を Fig. 5 に 示した。

\section{4. 考察}

\section{$4 \cdot 1$ 残留応力と力学模型}

巻線のクレージングが Table II で示すように伸長率 3-5\% で最大に発生するてとは Fig. 4 から放かるように3-5\%の伸 長率の時皮膜内の残留応力が最大となり, 伸長率と共に皮膜内残 留応力は增加しないととに原因する．すなわちクレージングはこ の残留応力を急激に緩和させる為に発生するものと理解できる。

Fig. 4 亿示されるような伸長率に対する皮膜内残留応内曲線に極 大が現れる現象を定性的に説明するのに，塑性の要素を入れた 4 要素モデルを用いてみた. Fig. 6 に4 要素モデルとそれぞれの要

Table II. Number of crazing vs. elongation.

\begin{tabular}{c|c}
\hline Elongation (\%) & $\begin{array}{c}\text { Number of crazing } \\
(\text { No/5 mm length })\end{array}$ \\
\hline 0 & 0 \\
1 & $5 \sim 20$ \\
3 & many \\
5 & many \\
7 & $90 \sim 140$ \\
9 & $60 \sim 70$ \\
11 & $50 \sim 60$ \\
13 & $40 \sim 50$ \\
15 & $30 \sim 40$ \\
17 & $20 \sim 30$ \\
\hline
\end{tabular}

(1) Sample : Polyesterimide (PEI).

(2) Samples were immersed in MEK for $5 \mathrm{sec}$. to cause crazing at $1 \mathrm{~min}$. after elongation.

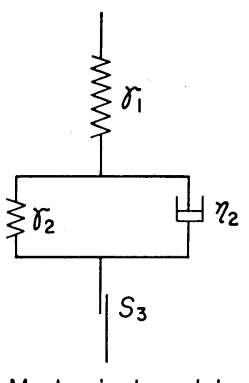

Mechanical model

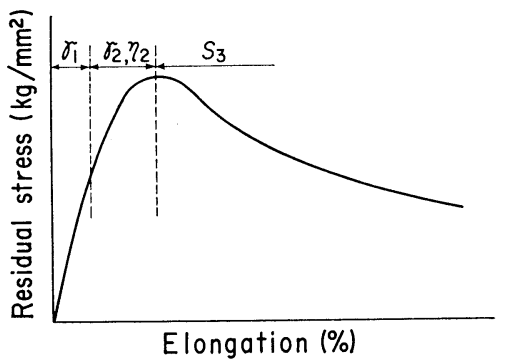

Fig. 6. Mechanical model ; instantaneous elasticity $\left(\gamma_{1}\right)$, retarded elasticity $\left(\gamma_{2}, \eta_{2}\right)$, and plastic flow $\left(S_{3}\right)$ in residual stress vs. elongation curves. 
素の働きを示す。

伸長率に対して残留応力が直線的に増加する弾性領域では，ス プリング $\gamma_{1}$ の働きにより弾性エネルギーが，また粘弾性領域で はスプリング $\gamma_{2}$ とダッシュポット $\eta_{2}$ の㗢きにより弾性エネルギ 一が皮膜内に蓄積される。 さらに伸長を続けると塑性流動領域と なり蓄積された弾性エネルギーが塑性流動 $S_{3}$ によって摩擦エネ ルギーとして一部消費される. 皮膜内の応力は伸長と共に増大す るが塑性流動領域に入ると低下を始める結果, 皮膜内残留応力曲 線に極大を生じる.

\section{$4 \cdot 2$ 引張応力と皮膜内残留応力}

次に，巻線から取出した円筒状皮膜の応力一ひずみ曲線と本方 法から求まる各伸長率に対する皮膜内残留応力曲線の関係を考察 する. Fig. 7 は試料ポリアミドイミドの引張応力曲線及びポリア ミドイミドを伸長した後 60 秒経過後の皮膜内残留応力曲線であ る. Fig. 7 の [1] の領域は引張応力が皮膜内残留応力よりも小 さい，乙れは応力ーひずみ曲線では円筒状皮膜を伸張する祭，皮 膜の不均一性の為に定速伸長の際, 伸びやすい部分が小さい力で 伸長されると考えられる。一方, 皮膜内残留応力を求める方法で は皮膜が導体に弱く接着した状態で伸長され，ほとんど導体の伸 びに伴って伸長される為皮膜の不均一性の影響がほとんどないと 考元らる. その為に皮膜内残留応力の方が引張応力に比較して 同一の伸長率に対して大きい值を示しているものと推定される. さらに伸長を続けて行くと, 引張応力はわずかではあるが増加す るのに対し皮膜内残留応力は低下する。乙の領域は [II]で示され る。乙の領域は蓄積されたエネルギーの塑型流動による消費を意 味し, 伸長の増加と共に蓄積エネルギーの消費が進むと考えられ る.

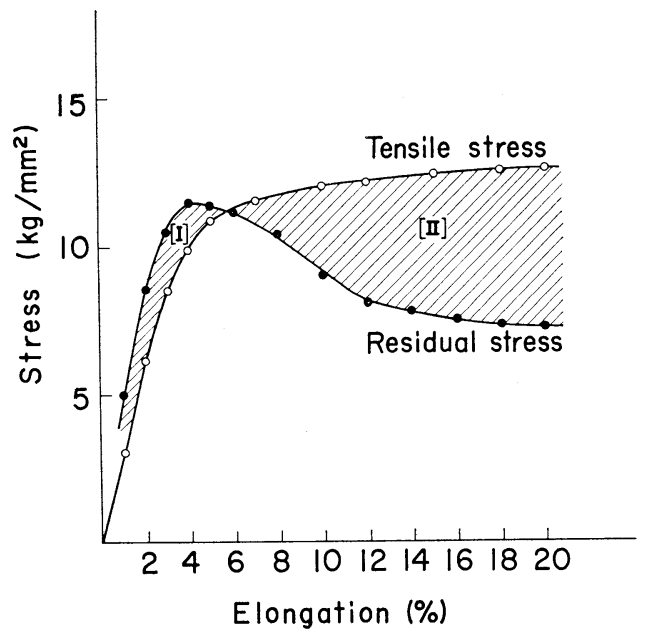

Fig. 7. Tensile stress vs. elongation curve of Polyamideimide (PAI) tubed film and residual stress vs. elongation curve of Polyamideimide (PAI) magnet wire film.

\section{$4 \cdot 3$ 皮膜内部残留応力緩和}

以上から皮膜内の残留応力がクレージングと密接に関係してい ることが判明したが，用いた三種類のサンプルの皮膜内残留応力 が時間と共にどのように変化するかを伸長率 $5 \%$ の場合について Fig. 8 亿示す. Fig. 8 からわかるように皮膜内の残留応力は架橋 型高分子のポリエステルイミド，直鎖状高分子ではあるが剛直性 に富むポリアミドイミド，直鎖状高分子のポリアミドの順に低く

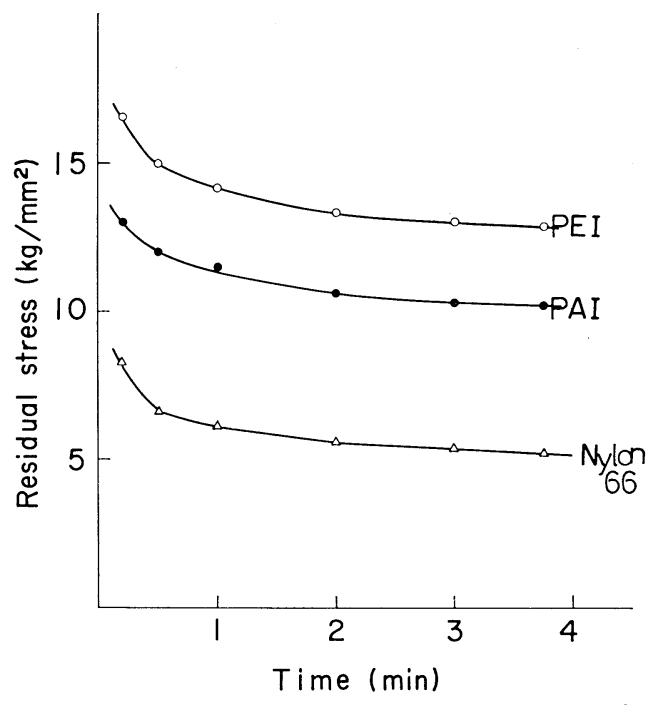

Fig. 8. Residual stress relaxation curves of Polyesterimide (PEI), Polyamideimide (PAI), and Polyamide (Nylon 66).

なっている，クレージングの発生がての順序で発生しがたくなる 傾向をもっている一つの原因は一定伸長率におけるこのような残 留応力の大小に起因していると考えられる. 一方, 同一のサンプ ルにおいても，伸長直後は残留応力が大きくクレージングを発生 しやすい傾向をもつが, 時間の経過と共に残留応力は低下しクレ ージングの発生は次第に減少する傾向をもつ。

\section{$4 \cdot 4$ クレージングの形態学的考察}

次に, クレージングがクラックであるのか, あるいは配向であ るのかを電子顕微鏡を用いて形態学的に考察する. Fig. 9 はポリ エステルイミドに発生したクレージングであり，Fig. 10 はその クレージングの先端部である.

Fig. 11はポリアミドに発生したクレージングであり,Fig. 12 は そのクレージングの先端部である. ポリエステルイミドに発生し たクレージングは明らかに幅 $0.1 \mu$ 程度のクラックである. ポリ エステルイミドに発生したクレージングの先端部は, Fig. 10 か らわかるように三つの領域に分けることができる。すなわち， (A) crack region, (B) crack transition region, (C) crack and crack transition region of under layer にわけられる. このう ち（B）と（C）の領域は皮膜の表面にクラックを発生してい ない. しかし皮膜の内部にクラックの発生が見られる。乙のとと は光学顕微鏡（1500倍）を用い（G）の部分において皮膜表面

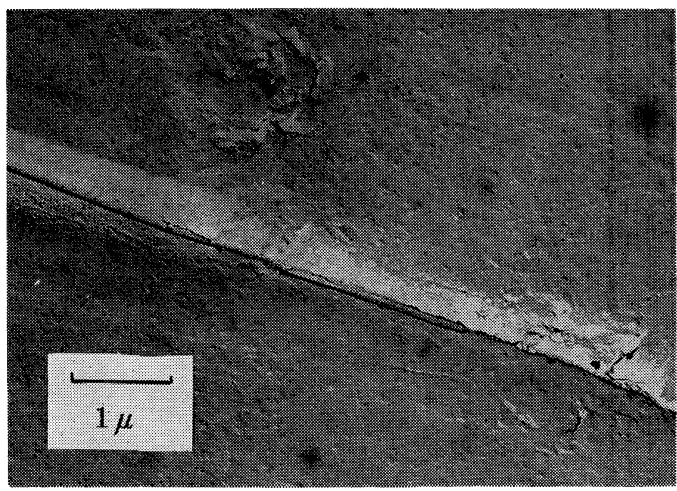

Fig. 9. Crazing of Polyesterimide (PEI), $(\times 10000)$. 


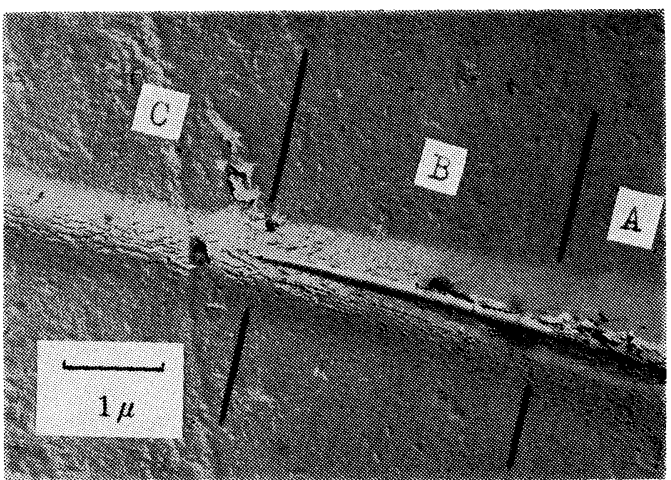

Fig. 10. Point of crazing of Polyesterimide (PEI), $(\times 10000)$. A, crack region; $\mathrm{B}$, crack ransition region; $\mathrm{C}$, crack and crack transition region of under layer.

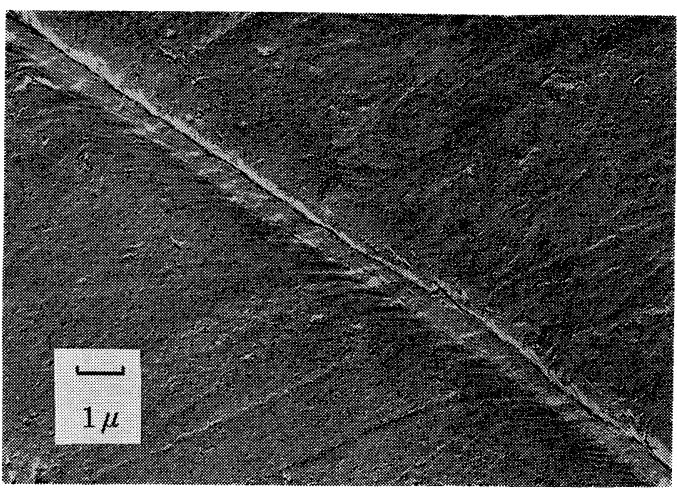

Fig. 11. Crazing of Polyamide (Nylon 66$),(\times 5000)$.

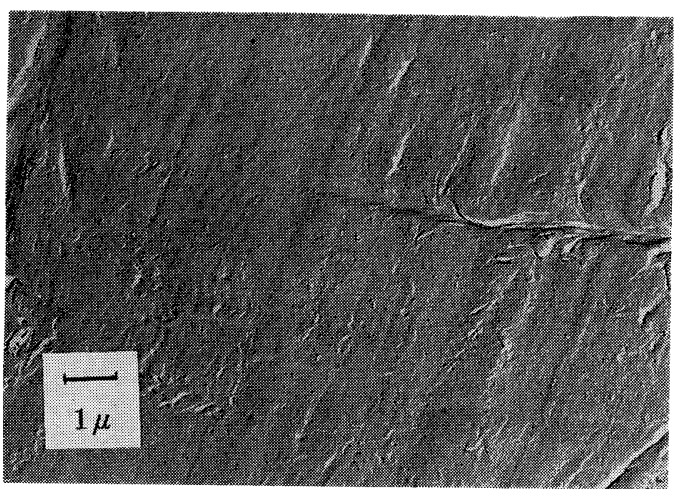

Fig. 12. Point of crazing of Polyamide (Nylon 66), $(\times 5000)$.

から内部へと焦点をずらしてゆくととによって, 表面㜿では観察 しえないクラックを内部で観察しうるととから確認するととがで きる。

巻線を伸長した後, 光学顕微鏡による観察のもとに溶剂を塗布 するとクレージングが巻線皮膜の表面から成長しているととがわ かる. しかし巻線はエナメル塗布焼付を複数回繰返して製造され るため, 内部程焼付の程度は進んでいる。 その結果，クラックは 内部程伝播しやすい，ポリエステルイミドにてのようなクレーシ ングが発生すると Table III に示すように絶縁耐力は大幅に低 下する．熱硬化性樹脂塗料を塗布焼付して製造される巻線のクレ ージングか配向であるという説があるが単なる配向であれば絶縁
Table III. Dielectric strength after crazing.

\begin{tabular}{c|c|c|c}
\hline \multirow{2}{*}{$\begin{array}{c}\text { Elongation } \\
(\%)\end{array}$} & \multicolumn{2}{|c|}{ PEI } & Nylon 66 \\
\cline { 2 - 4 } & $\mathrm{KV} / 50 \mu$ & $\mathrm{KV} / 50 \mu^{*}$ & $\mathrm{KV} / 50 \mu$ \\
\hline 0 & 6.6 & 6.8 & 5.7 \\
3 & 2.0 & 4.9 & 5.6 \\
6 & 2.1 & 5.2 & 5.3 \\
9 & 2.5 & 4.8 & 5.2 \\
12 & 2.6 & 4.6 & 5.0 \\
15 & 2.5 & 4.9 & 4.8 \\
\hline
\end{tabular}

(1) Sample length : $200 \mathrm{~mm}$.

(2) Dielectric strength was measured in $\mathrm{Hg}$ at room temperature.

(3) Samples were immersed in MEK for 5 sec. to cause crazing at $1 \mathrm{~min}$. after elongation.

(4)* Dielectric strength of magnet wire of which crazing was eliminated by heat annealing for $5 \mathrm{~min}$. at $220^{\circ} \mathrm{C}$.

耐力の低下に対する説明ができないと考えられる．著者等の実験 では巻線のクレージングが配向であるとは認めがたい.

一方, Fig. 11 及び 12 は分子鎖がクレージング発生部分で乱れ を生じている，クレージング発生部分で分子鎖の配向が示唆され る.ポリアミドに発生したクレージングは幅 $1 \mu$, 深さ $0.1-0.2 \mu$ 程度のクレージングであり導体に達するようなものではない，そ の為にクレージングが発生しても, ポリアミドの絶縁耐力の低下 はほとんどない (Table III)。

富永等がポリウレタン皮膜で配向説" を主張しているが，その 一つの根拠として発生したクレージングがある適当な熱処理によ って消失するてとを挙げている. 著者らの実験においてもクレー ジングは皮膜のガラス転移温度以上の温度で処理すると, 光学顕 微鏡スケールで消失させることができることを確認している。し かし電子顕微鏡スケール及び消失後の絶縁耐力等からはクレージ ングが完全に消失しないととも確認している ${ }^{9)}$ (Table III)。 レージングが光学顕微鏡スケールで消失するてとに対して著者ら はガラス転移温度以上の温度においては皮膜の分子鎖が分子運動 を活発に開始しそれに伴なう熱膨脹の結果，再び分子鎖が絡みあ いをもつ為クレージングが消失すると考える。

\section{5. 結論}

（1）巻線のクレージングは伸長率 $3-5 \%$ で最大に発生する. また，伸長後の皮膜内の残留応力は伸長率 3-5\%の時最大とな る、クレージングはての残留応力を急速に緩和させようとして発 生する. これは導体と皮膜との接着の弱い巻線を試料として用 い．皮膜内の残留応力を測定するてとによって定量的に説明でき る.

（2）熱硬化性樹脂塗料を数回塗布焼付して得られる巻線のクレ ージングはクラックである. クラックは Fig. 10 亿示すように皮 膜表面から内部へと進行している.

（3）直鎖状高分子のナイロン 66 樹脂を m-クレゾールに溶解し て塗布焼付したポリアミド線では, クレージングの発生を肉眼で は確認し難い．しかし，電子顕微鏡によると表面層に幅 $1 \mu$, 深

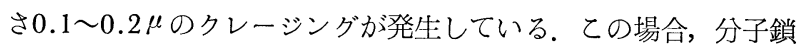
はクレージング発生部分で配向しているととが示唆される。 
（昭和49年10月 3 日，第22回レオロジ一討論会にて講演）

文 献

1) 増沢一興, 高分子化学, 13，211（1956）.

2）藤田英夫，平 岡 幸 郎，山田 哲三，高分子化学， 15，591 (1958).

3）富永孝志，阿蘇品英志，野田 謙，日東技報，16， No. 2 16 (1973).

4）佐藤行彦，高分子化学，22，145（1965).
5) Kambour, R.P. and R.W. Kopp, J. Polym. Sci., 7,183 (1969).

6) Isaksen, R.A., S. Newman, and R.J. Clark, J. Appl. Polym. Sci., 7, 515 (1963).

7) Bergeu, R.L., Jr., SPE J., 18, 667 (1962).

8) Peilstöcker, G., Ind. Plast. Mod., 14, 49 (1962).

9）増田重雄，糸賀輝雄，浅野信之，第23回高分子討論会要旨 集, 689 (1974). 